\title{
Thymine Metabolism in Pseudomonas aeruginosa Strain 1: The Presence of a Salvage Pathway
}

\author{
By A. A. POTTER, ${ }^{*} \dagger$ D. R. MUSGRAVE AND J. S. LOUTIT \\ Department of Microbiology, University of Otago, Dunedin, New Zealand
}

(Received 27 July 1981; revised 19 October 1981)

\begin{abstract}
Exogenous thymine was found to be taken up very slowly by Pseudomonas aeruginosa in comparison to other pyrimidines, and most of it was catabolized by the cell. The existence of a functional, although inefficient, thymine salvage pathway was demonstrated and this pathway operated more effectively when de novo thymidine nucleotide biosynthesis was inhibited by trimethoprim or methotrexate. The mechanism of thymine salvage by $P$. aeruginosa appears to be different from that of Escherichia coli and Pseudomonas acidovorans as thymidine was not incorporated into the DNA. Like $P$. acidovorans, $P$. aeruginosa lacked thymidine phosphorylase activity. Unsuccessful attempts were made to isolate thymine auxotrophs.
\end{abstract}

\section{INTRODUCTION}

In most bacteria, pyrimidine deoxyribonucleotide biosynthesis can occur via a de novo pathway and a salvage pathway (Kornberg, 1974). In the latter system, thymine and 2 -deoxyribosylthymine (thymidine) have been shown to be exclusively incorporated into the DNA of bacteria and this has provided a useful tool for specifically labelling the DNA with radioisotopes (Carmody \& Herriott, 1970). Whilst thymine is not readily incorporated by some bacteria because of the unavailability of endogenous deoxyribosyl donors (Breitman \& Bradford, 1964; O'Donovan \& Neuhard, 1970), this difficulty can be overcome by adding deoxyribonucleosides to the growth medium or alternatively by isolating thymine auxotrophs (Boyce \& Setlow, 1962; O'Donovan \& Neuhard, 1970). It is also known that thymidine is incorporated for only a short time because of its degradation by the enzyme thymidine phosphorylase (EC 2.4.2.4). The period of incorporation can be extended, however, if an exogenous source of deoxyribonucleosides is present, as this leads to competitive inhibition of thymidine phosphorylase (Boyce \& Setlow, 1962; Budman \& Pardee, 1967).

A de novo pathway of pyrimidine biosynthesis has been established in Pseudomonas aeruginosa and appears to be similar to that found in Escherichia coli (Isaac \& Holloway, 1968). There is, however, little information about the salvage of pyrimidines by $P$. aeruginosa (see Fig. 1 for salvage reactions in other organisms). It is known that thymidine is not incorporated at all by $P$. aeruginosa, even with the addition of deoxyribonucleosides to the growth medium (Holloway, 1975; Pemberton \& Clark, 1973). Pemberton \& Clark (1973) attempted to isolate mutants capable of incorporating thymidine, as well as thymine and thymidine auxotrophs, but with no success. Therefore, no DNA-specific labelling system is readily available for studies involving $P$. aeruginosa.

Kelln \& Warren $(1973,1974)$ reported that Pseudomonas acidovorans lacks a number of pyrimidine salvage enzymes, including uridine phosphorylase (EC 2.4.2.3), purinenucleoside phosphorylase (EC 2.4.2.1), cytidine deaminase (EC 3.5.4.5), thymidine

\footnotetext{
† Present address: Department of Biology, Carleton University, Ottawa, Canada, K 1S 5B6.
} 




Fig. 1. Pyrimidine salvage and interconversions in Escherichia coli, Salmonella typhimurium and Pseudomonas acidovorans. Reactions that are absent from $P$. acidovorans are shown by an oblique line $(/)$ across the reaction, while those absent from $P$. aeruginosa are denoted by an oblique line downwards ( $)$. Reactions which are missing in both $P$. acidovorans and $P$. aeruginos $a$ are denoted by an ' $X$ '. Enzymes are: (1) thymidine phosphorylase (EC 2.4.2.4); (2) deoxyribomutase (EC 2.7.5 -); (3) uridine phosphorylase (EC 2.4.2.3); (4) cytosine deaminase (EC 3.5.4.1); (5) cytidine (deoxycytidine) deaminase (EC 3.5.4.5); (6) thymidylate synthetase (EC 2.1.1.b); (7) deoxycytidine triphosphate deaminase; (8) uridine-5'-monophosphate pyrophosphorylase (uracil phosphoribosyltransferase, EC 2.4.2.9); (9) uridine kinase (EC 2.7.1.48); and (10) thymidine kinase (EC 2.7.1.21). Bases are identified as $\mathrm{C}$, cytosine; $\mathrm{U}$, uracil; and $\mathrm{T}$, thymine. Ribonucleosides are identified by the letter ' $r$ ' in front of the base, and deoxyribonucleosides by placing the letter ' $d$ ' in front of the base. Data are from Kelln \& Warren (1974), O’Donovan \& Neuhard (1970), Sakai et al. (1976) and this paper.

phosphorylase (EC 2.4.2.4), and probably uridine kinase (EC 2.7.1.48) and deoxycytidine kinase (EC 2.7.1.74) (Fig. 1). They were unable to label the DNA of $P$. acidovorans with isotopic thymine because of the lack of thymidine phosphorylase activity, but thymidine auxotrophs were isolated by aminopterin selection (Kelln \& Warren, 1973). These mutants lacked thymidylate synthetase (EC 2.1.1.b) activity and required an unusually high exogenous thymidine concentration for growth, greater than $250 \mu \mathrm{g} \mathrm{ml}^{-1}$.

The present study was undertaken in an effort to determine some of the factors involved in pyrimidine uptake and metabolism in $P$. aeruginosa. We were particularly concerned with the existence of a thymine salvage pathway, and our ultimate goal was the development of a DNA-specific labelling system.

\section{METHODS}

Bacteria. All strains used are derivatives of $P$. aeruginosa strain 1. The parent strain was $P$. aeruginosa OT15 (Loutit, 1969) which is prototrophic and carries the plasmid FP2. Strain OT700 is defective in the conversion of thymine to dihydrothymine, the first step of thymine catabolism ( $d h t$ ), and was derived from strain OT15 by $N$-methyl- $N^{\prime}$-nitro- $N$-nitrosoguanidine mutagenesis. Strain OT710 is a spontaneous 5-fluorouracil-resistant $u p p$ derivative of strain OT 15 . 
Media. The minimal medium of Davis \& Mingioli (1950) was routinely used, except that $0.2 \%(\mathrm{w} / \mathrm{v}$ ) sodium citrate, dihydrate, was used as the carbon source. Where different carbon and nitrogen sources were used, the same basal salts (without $\left(\mathrm{NH}_{4}\right)_{2} \mathrm{SO}_{4}$ l were provided and carbon and nitrogen sources were added to final concentrations of $0.2 \%(\mathrm{w} / \mathrm{v})$ and $0.1 \%(\mathrm{w} / \mathrm{v})$, respectively. The type of medium is referred to by listing the principal nitrogen source first followed by the principal carbon source (for example, glutamate/citrate medium contained glutamate as the nitrogen source and citrate as the carbon source). Difco Brain Heart Infusion supplemented with $4 \mathrm{~g}$ of $\mathrm{KNO}_{3} \mathrm{l}^{-1}$ (nitrate/BH) was routinely used as a complete liquid medium. For all solid media, Davis agar was added to $2.0 \%(\mathrm{w} / \mathrm{v})$. Amino acids were added to a concentration of $1.0 \mathrm{~mm}$ when required.

Radioisotopes. $\left[6-{ }^{3} \mathrm{H}\right]$ Thymidine, $\left[6-{ }^{3} \mathrm{H}\right]$ uracil, $\left.15-{ }^{3} \mathrm{H}\right]$ uracil and $\left[\right.$ methyl $-{ }^{3} \mathrm{H}$ thymine were obtained from Amersham.

Labelling of cells and DNA extraction. A culture $(10 \mathrm{ml})$ of $P$. aeruginosa strain OT15 grown overnight in nitrate/BH was washed and inoculated on to $200 \mathrm{ml}$ of minimal agar supplemented with $50 \mu \mathrm{Ci}\left(6 \cdot 25 \mathrm{Ci} \mathrm{mmol}^{-1}\right.$; $0.23 \mathrm{TBq} \mathrm{mmol}^{-1}$ ) of radioisotope in a $25 \times 15 \mathrm{~cm}$ tray. The cells were incubated overnight at $37^{\circ} \mathrm{C}$ and harvested in $50 \mathrm{ml}$ of saline/EDTA $(0.15 \mathrm{M}-\mathrm{NaCl}, 0.1 \mathrm{M}$-EDTA, pH 7.0). DNA was extracted by the procedure of Marmur (1961) and was stored in $10 \mathrm{ml}$ of phosphate/EDTA (50 mM-sodium phosphate, $10 \mathrm{mM}$-EDTA, $\mathrm{pH} 7.0)$ at $4{ }^{\circ} \mathrm{C}$.

DNA hydrolysis. DNA solutions in phosphate/EDTA were concentrated to $0.5 \mathrm{ml}$ by rotary evaporation or lyophilization, and these were added to thick-walled tubes with constricted necks, and dried. After adding $2.5 \mathrm{ml}$ of trifluoroacetic acid, the tubes were sealed and refluxed in cyclohexane at $158{ }^{\circ} \mathrm{C}$ for $1 \mathrm{~h}$, cooled in an ice $/ \mathrm{NaCl}$ mixture to reduce pressure, and the necks were carefully cut off. The trifluoroacetic acid was evaporated under a stream of air and the hydrolysed material resuspended in $20 \mu \mathrm{l}$ of sterile distilled water. This procedure is basically that of Carrier \& Setlow (1971).

Separation of base components. The hydrolysed DNA $(10 \mu \mathrm{l})$ was applied to a piece of Whatman no. 1 chromatography paper along with reference spots of adenine, guanine, cytosine, thymine and uracil. The chromatogram was placed in a tank with a small amount of solvent (isopropanol $/ \mathrm{HCl} /$ water, $171: 41: 39$, by vol.) in the bottom and was left to equilibrate for $4 \mathrm{~h}$. After equilibration, the solvent was added to the reservoir and the descending chromatogram was run for $36 \mathrm{~h}$. After drying, the positions of the reference bases were determined by viewing under ultraviolet light. The section containing the hydrolysed DNA was cut into $1.2 \times 2.5 \mathrm{~cm}$ strips and the radioactivity was measured under $5.0 \mathrm{ml}$ of butyl-PBD scintillation fluid $\left(6 \mathrm{~g}\right.$ litre $\mathrm{e}^{-1}$ in toluene) in a Packard Tri-Carb Liquid Scintillation Spectrometer, model 2002. The counting efficiency under these conditions was $12 \%$.

Kinetics of pyrimidine uptake. Cultures grown overnight in nitrate/BH were washed three times with sterile $0.85 \%(\mathrm{w} / \mathrm{v})$ saline and $30 \mathrm{ml}$ of liquid minimal medium in $250 \mathrm{ml}$ sidearm flasks were inoculated $\left(10^{7} \mathrm{cells}^{-1} \mathrm{ml}^{-1}\right.$. These were incubated with shaking at $37^{\circ} \mathrm{C}$ and the labelled pyrimidines were added when the cells were in the mid-exponential phase (generally $3 \cdot 5-4 \cdot 5 \mathrm{~h}$ ). Samples were removed at appropriate intervals and the radioactivity was measured. For the detection of radioactivity in macromolecules, a $0.5 \mathrm{ml}$ sample of cells was added to $10 \mathrm{ml}$ of ice-cold $5 \%(\mathrm{w} / \mathrm{v})$ trichloroacetic acid (TCA) and this was held on ice for $30 \mathrm{~min}$. The suspension was filtered through a Millipore filter (HAWP, $0.45 \mu \mathrm{m}$ pore size), washed once with $10 \mathrm{ml}$ cold $5 \%(\mathrm{w} / \mathrm{v}$ ) TCA and once with $3 \mathrm{ml}$ of $70 \%(\mathrm{v} / \mathrm{v})$ ethanol. Filters were dried at $70^{\circ} \mathrm{C}$ for $60 \mathrm{~min}$ and the radioactivity measured as described above. In order to detect radioactivity in compounds other than nucleic acids, a sample of cells was added to $10 \mathrm{ml}$ of $10 \%(\mathrm{w} / \mathrm{v}) \mathrm{TCA}$ and heated at $70-80^{\circ} \mathrm{C}$ for $60 \mathrm{~min}$. It was then treated as described for cold TCA-insoluble samples. The counting efficiency was $23 \%$ under these conditions.

Uptake of thymine in an overnight culture. Glutamate/citrate medium $(1 \mathrm{ml})$ containing thymine and [methyl ${ }^{3} \mathrm{H}$ |thymine was inoculated with $10^{7}$ cells and grown for $16 \mathrm{~h}$. The radioactivity was measured as described above for hot or cold TCA-insoluble samples.

Analogue sensitivity. Minimal agar plates with various carbon and nitrogen sources were inoculated on the surface with $10^{4}$ to $10^{7}$ cells. A crystal of the pyrimidine analogue to be tested was placed on the surface of the plate which was incubated at $37^{\circ} \mathrm{C}$ for $48 \mathrm{~h}$. In some cases, liquid minimal medium solutions containing varying concentrations of the analogue were inoculated with $10^{7}$ cells per $\mathrm{ml}$ and growth was determined after overnight incubation at $37^{\circ} \mathrm{C}$.

Effect of folate antagonists. A culture of $P$. aeruginosa strain OT700, grown overnight in nitrate/BH, was washed twice and $10 \mu \mathrm{l} \mathrm{samples} \mathrm{were} \mathrm{inoculated} \mathrm{into} \mathrm{two} \mathrm{series} \mathrm{of} \mathrm{tubes,} \mathrm{each} \mathrm{containing} 1 \mathrm{ml}$ of glutamate/citrate medium supplemented with $\left[\right.$ methyl ${ }^{3} \mathrm{H} \mid$ thymine at $1.0 \mu \mathrm{Ci}$ and $10 \mu \mathrm{g}$ of unlabelled thymine $\left(12.7 \mathrm{mCi} \mathrm{mmol}^{-1}\right.$; $0.47 \mathrm{GBq} \mathrm{mmol}^{-1}$ ). Trimethoprim [2,4-diamino-5-(3.4.5-trimethoxybenzyl)-pyrimidinel was added to one series of tubes at concentrations ranging downwards from $200 \mu \mathrm{g} \mathrm{ml} \mathrm{m}^{-1}\left(200,100,50,25,12,6,3,1.5,0 \mu \mathrm{g} \mathrm{ml}^{-1}\right)$, and methotrexate (4-amino- $N^{10}$-methylpteroyl-glutamic acid) was added to the other series at concentrations ranging downwards from $1250 \mu \mathrm{g} \mathrm{ml}^{-1}$ (in doubling fashion as for trimethoprim). After growth for $16 \mathrm{~h}$, the cold TCA-insoluble radioactivity was determined. In some experiments, methionine and/or vitamin B 12 was added and trimethoprim was then used at a concentration of $25 \mu \mathrm{g} \mathrm{mi}^{-1}$. 




Fig. 2. Labelling of the DNA of $P$. aeruginosa strain OT 15 with (a) isotopic uracil and (b) thymine. The cells were grown on $200 \mathrm{ml}$ of minimal agar containing $50 \mu \mathrm{Ci}\left(6.25 \mathrm{Ci} \mathrm{mmol}^{-1}\right)$ of the appropriate isotope and the DNA was extracted, hydrolysed, and separated by paper chromatography. The positions of adenine (A), cytosine $(\mathrm{C})$, thymine $(\mathrm{T})$ and uracil $(\mathrm{U})$ are indicated. $(a),\left[6{ }^{3} \mathrm{H}\right]$ Uracil; $\mathrm{O},\left[5-{ }^{3} \mathrm{H}\right]$ uracil; $\left(\right.$ b),$\left[\right.$ methyl- $\left.{ }^{3} \mathrm{H}\right]$ thymine.

\section{RESULTS}

\section{Establishment of pyrimidine salvage pathways}

When $P$. aeruginosa strain OT15 was grown on solid medium containing $\left[5-{ }^{3} \mathrm{H}\right]$ uracil, $\left[6-{ }^{3} \mathrm{H}\right]$ uracil or $\left[\right.$ methyl $\left.-{ }^{3} \mathrm{H}\right]$ thymine and the DNA was extracted, hydrolysed and separated into its base components, radioactivity was shown to be present in the DNA, and the distribution of radioactivity in the bases can be seen in Fig. 2. Exogenously added $\left[6-{ }^{3} \mathrm{H}\right.$ ] uracil supplied the cells with both dTTP and dCTP, while only the cytosine moiety of the DNA was labelled when $\left|5-{ }^{3} \mathrm{H}\right|$ uracil was provided. This suggested that dTMP was formed by methylation at the C-5 position on the pyrimidine ring of dUMP (Friedkin, 1973). The incorporation of $\left[\right.$ methyl- $\left.{ }^{3} \mathrm{H}\right]$ thymine into the DNA demonstrated that a functional thymine salvage pathway does exist in $P$. aeruginosa and therefore it should be possible to label the DNA specifically with isotopic thymine.

\section{Pyrimidine uptake}

The rates of incorporation of thymine, thymidine, uracil and uridine into the acid-insoluble fraction of strain OT15 are shown in Fig. 3. Both uracil and uridine were incorporated constitutively, and the lack of uridine uptake by strain OT710 (upp) indicated that uridine kinase is not active in $P$. aeruginosa. Uridine phosphorylase was quite active in strain OT15 as indicated by the efficient incorporation of uridine.

$\left[6-{ }^{3} \mathrm{H}\right]$ Thymidine was not incorporated at all and $\left[\right.$ methyl $\left.-{ }^{3} \mathrm{H}\right]$ thymine incorporation was only slight (Fig. 3). The addition of deoxyribose or ribose donors to the growth medium did not stimulate uptake of either compound. The deoxyribose donors tested were deoxyadenosine and deoxyguanosine, and the ribose donors were adenosine and uridine. These compounds were employed at varying concentrations up to $1 \mathrm{mg} \mathrm{ml}^{-1}$. In addition, the acid-soluble fraction of cells labelled with isotopic thymine and analysed by thin-layer and paper chromatography (Denhardt, 1969) had no radioactivity associated with the area on the chromatogram normally occupied by thymidine (data not shown). Labelled dTMP appeared to be present, however, indicating that there was a functional salvage pathway. Further evidence that thymidine was not involved in salvage was provided by a growth experiment in 


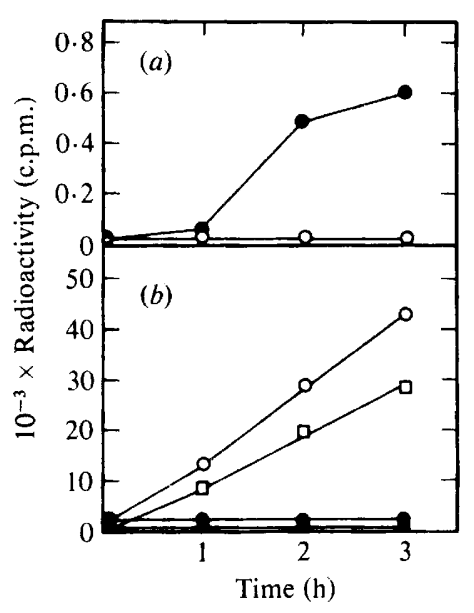

Fig. 3



Fig. 4

Fig. 3. Pyrimidine uptake by $P$. aeruginosa strains OT 15 and OT710. Bacteria were grown in liquid $\mathrm{NH}_{4}{ }^{+} /$citrate medium supplemented with isotopic uracil $\left(2.5 \mu \mathrm{g} \mathrm{ml}{ }^{-1}, 48.5 \mathrm{mCi} \mathrm{mmol}^{-1}\right)$, uridine $\left(2.5 \mu \mathrm{g} \mathrm{ml}^{-1}, 98 \mathrm{mCi} \mathrm{mmol}^{-1}\right)$, thymine $\left(4 \mu \mathrm{g} \mathrm{ml}^{-1}, 31.5 \mathrm{mCi} \mathrm{mmol}^{-1}\right)$ or thymidine $\left(2.5 \mu \mathrm{g} \mathrm{ml}^{-1}\right.$, $\left.97.1 \mathrm{mCi} \mathrm{mmol}^{-1}\right)$. The radioactivity was measured in cold TCA-insoluble material. (a) , Imethyl $-{ }^{3} \mathrm{H} \mid$ Thymine and $\mathrm{O},\left[6-{ }^{3} \mathrm{H}\right]$ thymidine uptake by strain OT $15 ;(b) \mathrm{O},\left[6-{ }^{3} \mathrm{H}\right]$ uridine, OT $15 ; \square$, $\left[6{ }^{3} \mathrm{H}\right]$ uracil, OT 15;,$\left[6{ }^{3} \mathrm{H}\right]$ uridine, OT710 upp; $\mathbf{0},\left[6{ }^{3} \mathrm{H}\right]$ uracil OT710 upp.

Fig. 4. Incorporation of thymine into a hot TCA-insoluble fraction by $P$. aeruginosa strain OT15 grown in various media. The cells were diluted 100 -fold into $30 \mathrm{ml}$ of the appropriate liquid medium supplemented with unlabelled thymine $\left(3 \mu \mathrm{g} \mathrm{ml}{ }^{-1}\right)$. After $3.5 \mathrm{~h}$ incubation, (methyl ${ }^{3} \mathrm{H}$ ) thymine was added $\left(20 \mu \mathrm{Ci}, 28 \mathrm{mCi} \mathrm{mmol}^{-1}\right)$ and the hot TCA-insoluble radioactivity in $0.5 \mathrm{ml}$ samples was measured. Values are corrected to a standard cell density. (a) O, Glutamate/citrate; 0 , glutamate/glucose; $\mathbf{\square}, \mathrm{NH}_{4}{ }^{+} /$citrate; $\square, \mathrm{NH}_{4}{ }^{+} /$glucose. (b) $\mathrm{O}$. Glutamate/glutamate; $\mathbf{O}$, glutamate/ acetate; $\square$, alanine/acetate; $\mathbf{\square}$, nitrate/BH.

which we showed that $P$. aeruginosa was unable to utilize thymidine as a carbon or nitrogen source when supplied at a concentration ranging from $0.01 \%(\mathrm{w} / \mathrm{v})$ to $1.0 \%(\mathrm{w} / \mathrm{v})$. Nucleosides such as uridine, adenosine and deoxyadenosine are catabolized efficiently by $P$. aeruginosa. Finally, we were unable to demonstrate either thymidine kinase or phosphorylase activity (results not shown). Consequently, we looked at thymine uptake under various conditions in an effort to determine the optimum conditions for its incorporation by the cell.

\section{Effect of growth medium on thymine uptake}

Most of the thymine which entered strain OT15 was catabolized since more than $70 \%$ of the radioactivity could be recovered in a hot TCA-insoluble fraction when cells were grown overnight in the presence of various carbon and nitrogen sources. As can be seen in Fig. 4, thymine incorporation was poor in the presence of $\mathrm{NH}_{4}{ }^{+}$, probably due to nitrogen metabolite repression. When $\mathrm{NH}_{4}{ }^{+}$was supplied at a growth limiting concentration, thymine catabolism was observed with all carbon sources tested (Table 1). Both glutamate and alanine allowed thymine degradation when used as nitrogen sources, and thymine degradation occurred when citrate or acetate was the principal carbon source. Glutamate/citrate was the medium which allowed maximum thymine uptake by strain OT15. In all experiments there was a lag of 2-3 $\mathrm{h}$ before thymine was catabolized.

\section{Optimum conditions for labelling}

The optimum ratio of isotopic to unlabelled thymine was investigated in order to improve the labelling efficiency. Isotopic and unlabelled thymine were added to cultures of strain 
Table 1. Incorporation of $\left[\right.$ methyl $\left.-{ }^{3} \mathrm{H}\right]$ thymine into a hot TCA-insoluble fraction by $P$. aeruginosa strain OT15 growing in various media

Portions $(10 \mu \mathrm{l})$ of a washed overnight culture were inoculated into $1 \mathrm{ml}$ portions of various media supplemented with $\left[\right.$ methyl- $\left.{ }^{3} \mathrm{H}\right]$ thymine $\left(5 \mu \mathrm{g} \mathrm{ml}^{-1}, 0.25 \mathrm{Ci} \mathrm{mmol}^{-1}\right)$. The cells were grown overnight, the cell density measured and the radioactivity in a hot TCA-insoluble fraction determined.

Thymine incorporation*

\begin{tabular}{|c|c|c|}
\hline \multicolumn{3}{|c|}{ Nitrogen source } \\
\hline $\begin{array}{c}\mathrm{NH}_{4}^{+} \\
(10 \mathrm{mM})\end{array}$ & $\begin{array}{l}\mathrm{NH}_{4}^{+} \\
(1 \mathrm{mM})\end{array}$ & $\begin{array}{c}\text { Glutamate } \\
(10 \mathrm{~mm})\end{array}$ \\
\hline
\end{tabular}

$\begin{array}{lccr}\text { Glucose } & 39 & 128 & 82 \\ \text { Citrate } & 44 & 132 & 174 \\ \begin{array}{l}\text { Acetate } \\ \begin{array}{l}\text { Glutamate as carbon and } \\ \text { nitrogen source }\end{array} \\ \begin{array}{l}\text { Minimal medium } \\ \text { ND }\end{array}\end{array} & 39 & 193 & 42 \\ & 19 & \text { ND } & 70 \\ & & & \text { ND }\end{array}$

ND, Not done.

* Units are c.p.m. corrected to a standard cell density [c.p.m. (Eel nephelometer unit) ${ }^{-1}$. The conversion factor is 100 Eel nephelometer units $=2 \times 10^{9}$ cells ml$^{-1}$.

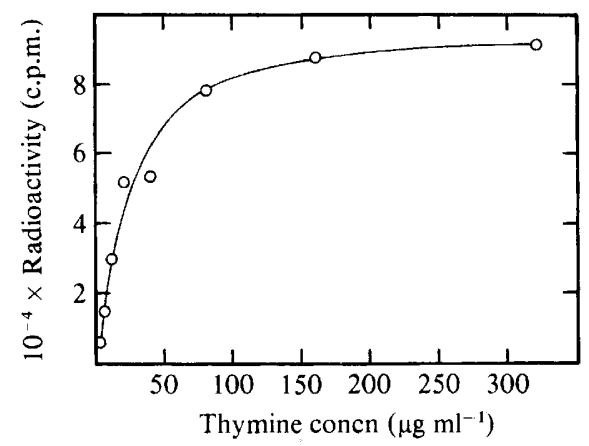

Fig. 5. Effect of exogenous thymine concentration on thymine uptake by $P$. aeruginosa strain OT15. The cells were grown for $16 \mathrm{~h}$ in glutamate/citrate medium supplemented with $\left[\right.$ methyl $-{ }^{3} \mathrm{H} \mid$ thymine $\left(31.5 \mathrm{mCi} \mathrm{mmol}^{-1}\right)$ and unlabelled thymine at various concentrations. The radioactivity in a cold TCA-insoluble fraction was measured.

OT15 in the exponential phase at various ratios and after $3 \mathrm{~h}$ the radioactivity in the acid-insoluble fractions was measured. The ratio which yielded the greatest uptake was between $31.5 \mathrm{mCi} \mathrm{mmol}^{-1}\left(1.17 \mathrm{GBq} \mathrm{mmol}^{-1}\right)$ and $42.0 \mathrm{mCi} \mathrm{mmol}^{-1}\left(1.55 \mathrm{GBq} \mathrm{mmol}^{-1}\right)$.

The extent to which exogenous thymine is catabolized or incorporated into the DNA is largely dependent upon its concentration in the growth medium. Escherichia coli, in the presence of deoxyribosyl supplements, shows saturation of thymine utilization at a concentration of less than $7 \mu \mathrm{g} \mathrm{ml}^{-1}$ but saturation occurs at a concentration greater than $50 \mu \mathrm{g} \mathrm{ml}^{-1}$ in the absence of these supplements (Kammen, 1967). In P. aeruginosa, thymine utilization was not saturated until an exogenous concentration of greater than $200 \mu \mathrm{g} \mathrm{ml}^{-1}$ was reached (Fig. 5) and as mentioned above, the addition of deoxyribosyl donors to the growth medium had no effect on thymine uptake.

\section{Pyrimidine analogue sensitivity}

Pseudomonas aeruginosa was found to be sensitive to most uracil analogues and resistant to thymine analogues, reflecting the efficiency of incorporation of the two compounds. A 


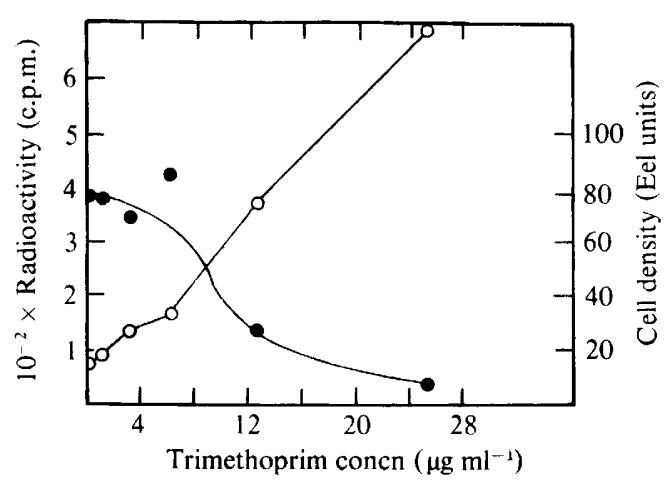

Fig. 6



Fig. 7

Fig. 6. Effect of trimethoprim on the growth and incorporation of thymine by $P$. aeruginosa strain OT 700. The cells were labelled with $\mid$ methyl ${ }^{3} \mathrm{H} \mid$ thymine $\left(10 \mu \mathrm{g} \mathrm{ml}{ }^{-1}, 12.7 \mathrm{mCi} \mathrm{mmol}^{-1}\right)$ in the presence of trimethoprim. Further details are given in Methods. The radioactivity in a cold TCA-insoluble fraction was measured. $O$, Thymine incorporation; 0 , growth (measured in Eel nephelometer units; 100 Eel units $=2 \times 10^{9}$ cells $\mathrm{ml}^{-1}$ ).

Fig. 7. Effect of methionine and vitamin B12 on the trimethoprim-stimulated incorporation of thymine by $P$. aeruginosa strain OT700. The cells were labelled with $\mid$ methyl ${ }^{3} \mathrm{H} /$ thymine $\left(10 \mu \mathrm{g} \mathrm{m} \mathbf{l}^{-1}, 12 \cdot 7 \mathrm{mCi}\right.$ $\mathrm{mmol}^{-1}$ ) in the presence of trimethoprim, methionine and/or vitamin B 12 as described in Methods. The radioactivity in a cold $\mathrm{TCA}$-insoluble fraction was measured. $O$, Trimethoprim + methionine; $O$, trimethoprim + methionine + vitamin B $12 ; \square$, methionine alone.

gradient of toxicity was observed with 5-fluorouracil, 5-chlorouracil and 5-bromouracil in which the sensitivity was inversely related to the ionic radius of the halogen at the C-5 position. Thus, 5-fluorouracil was very toxic while 5-bromouracil had no apparent effect on the cells. The chlorine atom, therefore, gave rise to a toxicity between 5-fluorouracil and 5-bromouracil.

Mutation to 5-fluorouracil resistance resulted in the cessation of uracil uptake and the acquisition of 6-azauracil resistance, which indicated that a functional uracil phosphoribosyltransferase was absent from the resistant strain (O'Donovan \& Neuhard, 1970). Only one level of resistance to 5-fluorouracil was observed and resistant strains could not be sensitized to lower fluorouracil concentrations in the presence of exogenous adenosine or deoxyadenosine, which suggested that the enzymes uridine kinase, thymidine kinase and thymidine phosphorylase were absent (Ahmad \& Pritchard, 1969).

In view of the absence of deoxythymidine kinase it is not surprising that 5fluorodeoxyuridine was not inhibitory at concentrations as high as $1 \mathrm{mg} \mathrm{m}{ }^{-1}$, since it functions as an inhibitor only after conversion to 5 -fluorodeoxyuridine monophosphate. This last compound functions as an inhibitor of thymidylate synthetase.

\section{Effect of folate antagonists}

Trimethoprim and methotrexate are potent inhibitors of dihydrofolate reductase (Friedkin, 1973; Seydel et al., 1972) and the biosynthesis of tetrahydrofolate is inhibited in the presence of these compounds. The de novo formation of dTMP requires a tetrahydrofolate-dependent methylation of dUMP and therefore one would expect the thymine salvage pathway to operate more efficiently in the presence of trimethoprim or methotrexate.

The increase in thymine incorporation by strain OT700 in the presence of trimethoprim is illustrated in Fig. 6. Methotrexate yielded the same result, although it did not appear to be as 
toxic as trimethoprim. Both of these compounds stimulated thymine incorporation, although trimethoprim did not appear to promote thymine uptake at concentrations greater than $25 \mu \mathrm{g}$ $\mathrm{ml}^{-1}$ because of low cell yields. The strain OT700 is defective in thymine catabolism and therefore the increase in thymine incorporation must have been due to salvage. In support of this, no increased hot TCA-insoluble radioactivity was observed in the presence of the antifolate compounds.

Tetrahydrofolate is also required for methionine biosynthesis (Hatch et al., 1961) and therefore the effect of exogenous methionine and vitamin B 12 on the trimethoprim-stimulated incorporation of thymine was examined. Vitamin B 12 is a necessary co-factor for the $m e t H$ protein of $E$. coli (Cauthen et al., 1966). When the two compounds were added to the growth medium, thymine incorporation by strain OT700 decreased to the basal level (Fig. 7). Neither methionine nor vitamin B 12 had any effect on thymine salvage in the absence of trimethoprim (only the result for methionine is shown), and therefore the incorporation of thymine by strain OT700 must have been the result of thymine salvage.

\section{Thymine auxotrophs}

Our results suggested that $P$. aeruginosa was able to incorporate thymine and convert it to the corresponding nucleotide. Since the thymine salvage pathway operated more efficiently when the de novo biosynthesis of dTMP was impaired, the isolation of thymine auxotrophs should be possible. Trimethoprim has been used to select for thymine auxotrophs in many genera (O'Donovan \& Neuhard, 1970) but efforts have been unsuccessful with $P$. aeruginosa (Holloway, 1975; Pemberton \& Clark, 1973).

Minimal agar plates containing various carbon and nitrogen sources and concentrations of folate antagonists were inoculated with $10^{9}, 10^{8}$ or $10^{7}$ viable cells from washed cultures grown overnight in nitrate/ $\mathrm{BH}$. Normally, cells were not treated with a mutagen, but in some cases $N$-methyl- $N^{\prime}$-nitro- $N$-nitrosoguanidine was used as previously described (Loutit, 1969). A total of $6 \times 10^{12}$ cells were screened and no thymine auxotrophs were obtained. However, some clones exhibiting the Thy A phenotype of $B$. subtilis (Neuhard et al., 1978) were isolated on $\mathrm{NH}_{4}^{+}$/citrate agar containing trimethoprim, sulphadiazine and thymine at 80,20 and $300 \mu \mathrm{g} \mathrm{ml}^{-1}$, respectively, and also from glutamate/citrate agar supplemented with thymine at $300 \mu \mathrm{g} \mathrm{ml}{ }^{-1}$ and trimethoprim + sulphadiazine at $160+40 \mu \mathrm{g} \mathrm{ml}^{-1}$, respectively. The parental strains were OT15 and OT700. These mutants required thymine for growth only in the presence of trimethoprim (the ThyA phenotype) but changed within one or two subcultures to a trimethoprim-resistant thymine-prototrophic phenotype indistinguishable from other isolates. This suggested that there may be more than one mechanism for the de novo biosynthesis of dTMP and presumptive thyA mutants were all subjected to a second round of selection with trimethoprim and sulphadiazine present at 750 and $80 \mu \mathrm{g} \mathrm{ml}^{-1}$, respectively. No thymine auxotrophs were detected.

\section{DISCUSSION}

DNA-specific labelling should be possible in bacteria provided a functional thymine salvage pathway exists. We have demonstrated such a pathway in $P$. aeruginosa and shown that thymine incorporation can be stimulated by the inhibition of de novo dTMP biosynthesis with trimethoprim. Most of the thymine taken up by the cell was normally catabolized, but under certain conditions which did not permit catabolism, all of the thymine taken up entered the DNA. Thymine incorporation into the DNA was most efficient when the cells were grown in liquid minimal medium containing $\mathrm{NH}_{4}{ }^{+}$, which repressed thymine catabolism, and isotopic thymine at a specific activity of $31.5 \mathrm{mCi} \mathrm{mmol}^{-1}$. Alternatively, a strain unable to catabolize thymine $(d h t)$ incorporated more thymine into the DNA. The amount of thymine incorporated under these conditions was small and there was a 2-3 h lag before it entered the 
cell, making it impossible to pulse-label the DNA. The folate antagonists trimethoprim and methotrexate stimulated thymine salvage, and since methotrexate does not appear to affect the growth rate of $P$. aeruginosa when supplied at a concentration of $1 \mathrm{mg} \mathrm{m}^{-1}$, it may prove useful when one requires a greater labelling efficiency.

Previous attempts to isolate thymine auxotrophs of $P$. aeruginosa were unsuccessful (Holloway, 1975; Pemberton \& Clark, 1973) and ours were no exception. The de novo biosynthesis of dTMP could be blocked by the addition of trimethoprim to the growth medium, but perhaps the salvage pathway does not operate efficiently enough to give thymine auxotrophs a growth advantage over normal cells. Alternatively, there may be more than one pathway for the de novo biosynthesis of dTMP. Neuhard et al. (1978) demonstrated that $B$. subtilis possessed two genetically distinct thymidylate synthetases, one of which was heat-labile. We have been able to isolate thy $A$ mutants of $P$. aeruginosa (requiring thymine only in the presence of trimethoprim), but they were extremely unstable. This suggested to us that a second trimethoprim-sensitive mechanism for thymine nucleotide biosynthesis may be active in $P$. aeruginosa. This would explain the difficulties encountered in thymine auxotroph isolation and the high level of resistance of clinical isolates of $P$. aeruginosa to trimethoprim/suphamethoxazole (Bushby, 1973).

Although a functional thymine salvage exists, it would appear to be different from that found in $E$. coli and $P$. acidovorans since thymidine was not utilized. In support of this lack of ability to utilize thymidine, it has not been possible to demonstrate the presence of either deoxythymidine kinase or phosphorylase in P. aeruginosa. Further evidence for the absence of deoxythymidine kinase was provided by the lack of toxicity of 5-fluorodeoxyuridine even when this compound was present at a concentration of $1.0 \mathrm{mg} \mathrm{ml}^{-1}$. 5-Fluorodeoxyuridine must be converted to the monophosphate derivative by deoxythymidine kinase to be toxic. but it had no effect on $P$. aeruginosa.

An alternative explanation for the lack of thymidine incorporation may be that $P$. aeruginosa is unable to transport the compound into the cell. This, however, is doubtful in light of the observation that thymidine kinase activity was not present in cell-free extracts. Also, Pemberton \& Clark (1973) unsuccessfully attempted to isolate mutants capable of thymidine uptake and thymidine auxotrophs following mutagenesis. Therefore, it seems more probable that thymidine cannot be converted to the nucleotide by $P$. aeruginos $a$ strain 1 .

Kelln \& Warren $(1973,1974)$ showed that $P$. acidovorans lacks thymidine phosphorylase activity but thymidine phosphorylase activity is present. They were therefore able to isolate thymidine auxotrophs in which the DNA could be labelled with isotopic thymidine. Pseudomonas aeruginosa appears to be similar in that deoxythymidine phosphorylase activity is absent, but the two species probably have different mechanisms for thymine salvage since the DNA of $P$. aeruginosa can be labelled with isotopic thymine, whereas $P$. acidovorans has no mechanism for converting thymine to the nucleotide (Kelln $\&$ Warren, 1974).

This research was supported by a grant from the Medical Research Council of New Zealand. A. A. P. was the recipient of an MRC Postgraduate Scholarship. The technical assistance of Mr I. J. Robertson is gratefully acknowledged.

\section{REFERENCES}

Ahmad, S. I. \& PRitchard, R. H. (1969). A map of four genes specifying enzymes involved in catabolism of nucleosides and deoxyribonucleosides in Escherichia coli. Molecular and General Genetics 104, 351-359.

Boyce, R. P. \& Setlow, R. B. (1962). A simple method of increasing the incorporation of thymidine into the deoxyribonucleic acid of Escherichia coli. Biochimica et biophysica acta 61, 618-620.

Breitman, T. R. \& Bradford, R. M. (1964). The induction of thymidine phosphorylase and excretion of deoxyribose during thymine starvation. Biochemical and Biophysical Research Communications 17. 786-791. 
Budman, D. R. \& Pardee, A. B. (1967). Thymidine and thymine incorporation into deoxyribonucleic acid: inhibition and repression by uridine of thymidine phosphorylase of Escherichia coli. Journal of Bacteriology 94, 1546-1550.

Bushby, S. R. (1973). Sensitivity testing with trimethoprim/sulphamethoxazole. Journal of the Australian Medical Association, Wellcome Symposia 1, 10-18.

Carmody, J. M. \& Herriott, R. M. (1970). Thymine and thymidine uptake by Haemophilus influenzae and the labelling of deoxyribonucleic acid. Journal of Bacteriology 101, 525-530.

CARrier, W. L. \& Setlow, R. B. (1971). The excision of pyrimidine dimers. Methods in Enzymology 21, 230-244.

Cauthen, S. E., Foster, M. A. \& Woods, D. D. (1966). Methionine biosynthesis by extracts of Salmonella typhimurium. Biochemical Journal 48, 630-639.

Davis, B. D. \& Mingioli, E. S. (1950). Mutants of $E$. coli requiring methionine and vitamin B12. Journal of Bacteriology 60, 17-28.

DenhaRdT, D. T. (1969). Formation of ribosylthymine in Escherichia coli. Journal of Biological Chemistry 244, 2710-2715.

FriedKIN, M. (1973). Thymidylate synthetase. Advances in Enzymology 38, 235-292.

Hatch, F. T., Larrabee, A. R., Cathou, R. \& Buchanan, J. M. (1961). Enzymatic synthesis of the methyl groups of methionine. I. Identification of the enzyme and co-factors involved in the system isolated from Escherichia coli. Journal of Biological Chemistry 236, 1095-1108.

Holloway, B. W. (1975). Genetic organisation of Pseudomonas. In Genetics and Biochemistry of Pseudomonas, pp. 133-162. Edited by P. H. Clarke \& M. H. Richmond. New York: John Wiley.

IsaAC, J. H. \& Holloway, B. W. (1968). Control of pyrimidine biosynthesis in Pseudomonas aeruginosa. Journal of Bacteriology 46, 1732-1741.
KAMMEN, H. O. (1967). Thymine metabolism in Escherichia coli. 1. Factors involved in utilization of exogenous thymine. Biochimica et biophysica acta 134, 301-311.

Kelln, R. A. \& W ARren, R. A. J. (1973). Obligate thymidine auxotrophs of Pseudomonas acidovorans. Journal of Bacteriology 113, 510-511.

Kelln, R. A. \& Warren, R. A. J. (1974). Pyrimidine metabolism in Pseudomonas acidovorans. Canadian Journal of Microbiology 20, 427-433.

KorNBERG, A. (1974). DNA synthesis, lst edn, pp. 29-54. San Francisco: W. H. Freeman.

LouTIT, J. S. (1969). Investigation of the mating system of Pseudomonas aeruginosa strain 1. V. The effect of $N$-methyl- $N^{\prime}$-nitro- $N$-nitrosoguanidine on a donor strain. Genetical Research 14, 103-109.

MARMUR, J. (1961). A procedure for the isolation of DNA from microorganisms. Journal of Molecular Biology 3, 208-218.

Neuhard, J., Price, A. R., Schack, L. \& Thomassen, E. (1978). Two thymidylate synthetases in Bacillus subtilis. Proceedings of the National Academy of Sciences of the United States of America 75, 1194-1198.

O’Donovan, G. A. \& Neuhard, J. (1970). Pyrimidine metabolism in microorganisms. Bacteriological Reviews 34, 278-343.

Pemberton, J. M. \& Clark, A. J. (1973). Detection and characterization of plasmids in Pseudomonas aeruginosa strain PAO. Journal of Bacteriology 114, 424-433.

SaKai, T., Yu, T. \& OMata, S. (1976). Distribution of enzymes related to cytidine degradation in bacteria. Agricultural and Biological Chemistry 40, 18931895.

Seydel, J. K., Wempe, E., Miller, G. H. \& Miller, L. (1972). Kinetics and mechanisms of action of trimethoprim and sulphonamides, alone or in com bination, upon Escherichia coli. Chemotherapy 17. 217-238. 